\title{
NEW HAMPSHIRE'S EXPERIMENT IN USING PRISON LABOR TO SUPPORT PAUPERS
}

\author{
By Elwin L. Page, \\ Chairman, Workhouse Investigation Commission, Concord, N. H.
}

In the early history of the State of New Hampshire thelegislature made provision for workhouses for the support and maintenance of the poor and the punishment of idle and disorderly persons. By an act passed in $\mathbf{1 7 9 1}$ the various towns were authorized to provide such houses if they saw fit, while the various counties were empowered to institute houses of correction for minor offenders. As the laws of settlement then in vogue did not require the counties to do much by way of support of paupers, no provision seems to have been made for county almshouses. ${ }^{1}$ This was the time of transition from the ancient process of binding out the poor to labor to the newer method of keeping them at poor farms. Both methods were at this time legal. ${ }^{2}$

Such substantially was the situation until 1828. In passing, it is worth while to mention the fact that this period apparently saw the emergence of the idea of out-of door employment for prisoners. The justices of the superior court were authorized in 1816 to fix the limits of the jail-yards in the several counties at not more than 200 rods "each way from said jails."

In 1828 the legislature took the next step, by authorizing counties to maintain lands and buildings, not only for a house of correction, but also for the accommodation, support and employment of the poor who might be chargeable to the counties." But the evolution was slow, and as a matter of fact the poor were mostly cared for by the towns. From 1828, therefore, there was for a time a system of poor relief mainly by the towns and upon town farms. Upon these farms, in many cases, were town houses of correction, but on the other hand many towns made no provision for offenders and in such case idle and disorderly persons (which in those days included jugglers,

1 Laws, 1797 , pp. 345-348. In default of county houses of correction, minor offenders under county jurisdiction were confined at the common prison (county jail).

- Perpetual Laws, 1780 , p. 172; Laws, 1797. pp. 348-349. The time of transition spoken of was of long duration. Even in late provincial times some towns maintained workhouses for the poor. Provincial Laws, $I 771$, ch. 61, sec. 7.

- Laws, 1816, p. 95.

Laws, 1830, p. 302. 
pipers, fiddlers and adepts at magic art) were sent, in default of a county house of correction, to the common jail. ${ }^{5}$

The actual institution of a county farm, though legalized in 1828, did not occur until 1846, when Hillsborough county, the most populous, set the example. It is interesting to note that industrial pressure, and not legislation, produced the county farm. The middle of the nineteenth century was marked by the influx of a large Irish and French-Canadian immigration which displaced the native stock as operatives in textile mills. The generation which saw the passing of the mill-worker of whom Lucy Larcom at Lowell was an advanced type, saw the county farm come in and the town farm go out. The new workers, unattached to the native soil and with no accumulation of prosperity behind them, ill-paid as all new workers are, were peculiarly apt candidates for the almshouse. Having no town settlement, they became county charges upon becoming paupers. It was soon apparent that the county could more cheaply care for them in a centralized almshouse than by allowing them to go to the various town farms, where the county must pay their board. Moreover, the town farms were not lacking in the abuses common to such instititions, and a county almshouse could give the paupers better treatment. Naturally Hillsborough, the textile county, first felt this pressure and first met the need. By the early seventies, all ten counties had their poor farms.

The great majority of paupers having now no town settlement and the population of the town alsmhouses being restricted to town paupers, the municipalities soon found the upkeep of local almshouses too expensive. Town farms were sold in large numbers and town charges sent to county farms. This shift was accelerated by the passage of a law in 1875 abolishing all town pauper settlements acquired prior to 1860.6 Soon the universal practice was for town paupers not given out-door aid to be sent to the county farm, where the town paid their board ${ }^{7}$-just the converse of the situation before industrial immigration set in. Towns may still maintain farms, but only one chooses to do so.

The centralization of paupers into county groups having been thus effected, it remained to bring about some centralization of the

${ }^{5}$ Laws, 1830 , p. 303 ; R. S. (1843), pp. 137, 139, 225, 462; G. S. (1867) cc. 24, 74, 75, 268. To this day the law as to binding out paupers persists, although it is obsolete.

6 G. L. ch. 81 , sec. 6 .

7 Such disposition of town paupers was legalized in 1860. 
minor offenders. Most of the latter being dragged into the local police net and sentenced by the local justice or police court, have always been viewed as in a sense wards of the town. As already seen, they were sent to one of the following institutions, in order of preference: (1) the town house of correction, at the town farm; (2) the county house of correction; or (3) the county jail.

With the gradual abolition of the town farm, the first institution disappeared. At first, the counties having made no provision for houses of correction under the laws of 1791 and 1828, the only alternative was to commit the prisoners to jail. There, however, they languished in the idleness typical of the county jail; for the vision of the 400-rod jail-yard caught in 1816 had vanished.

Hillsborough county again led the way, and in 1869 instituted a house of correction in connection with its poor farm. The county commissioners, in their report for that year (p. 6), assign the two advantages of this new venture which apparently were paramount in their minds: (1) the desirability of not having simple drunks or slight offenders go to jail with hardened criminals; and (2) the fact that the six prisoners confined at the farm earned their board, whereas at the jail the county must have allowed the jailer their board and key fees. The second reason, on the whole, seems to have been the weightier one. It was the one relied upon in Rockingham county; ${ }^{8}$ and in Strafford county also, though in the latter the additional argument was advanced that, the paupers being unable to do all of the farm work, the prisoners' labor obviated hiring farm hands. ${ }^{9}$ In Cheshire county the reasons assigned were "the insufficiency of our jail, allied to the interests of humanity, as well as financial considerations."10 Merrimack county's reason was that there was work at the farm, idleness at the jail. ${ }^{11}$ The reasons given in the other counties do not appear of record, but it is generally understood that in all counties the "financial considerations" had much, if not most, to do with the sending of prisoners to the farms. Every farm had its prisoners by the middle nineties, and most of them by the middle seventies. The movement of prisoners from town to county farms was practically completed by legislation in 1899 , when a law was passed declaring that county farm buildings and county jails should

Rockingham Commissioners' Report, 1870-71, p. 4.

' Strafford Commissioners' Report, $1878-0$, p. 25.

${ }^{10}$ Cheshixe Commissioners' Report, $1875-6$, p. 18.

1 Merrimack Commissioners' Report, $1887-88$, p. 4. 
be deemed houses of correction.12 The consideration which led the legislature thus to define and adopt the practice which had been growing up for thirty years was the financial one.

The justification of this movement rests, in any event, upon one or both of two theories: (1) that men are better off at work upon the farms than in idleness at the jails; (2) that their work upon the farm is of financial advantage to the farm, in that it obviates the hiring of extra laborers and so decreases the net cost of supporting the paupers. These theories will be discussed briefly in their order.

There can be no denying the fact that the prisoners are better off at work on the farm than idle in jail. The work furnished at the county farms, being mostly out-doors is undoubtedly beneficial to this class of offenders. The men cultivate the farms under supervision. With very rare exceptions are the guards armed. Escapes are, on the whole, few. On farms having wood-lots, the men cut firewood in winter. They help care for the stock; paint and do other repairs on the buildings; work upon new construction and at landimprovement. In a few counties they go in limited numbers to help neighboring farmers, or work upon town road repairs, the county being paid for their labor. In one county the road gang was made more efficient by allowing the men a little each day in addition to what was paid the county. This same county contracted its prisoners to build a new house of correction at $\$ 1.25$ a day, $\$ 1$ to the county and 25 cents to the prisoner. All the contractor furnished was material and superintendence.

This is all excellent, as far as it goes. During the early days of commitments to the county farms, the few prisoners found ample employment. But it was soon found that in this severe northern climate there was altogether too little winter work, and the winter was the time when the prison population was the largest. The prisoners did not find wood to cut on most of the farms, and consequently their winter activities were confined to chores, getting in the ice and now and then breaking out the neighboring roads. This condition was remarked upon in the Cheshire county reports of 1876$77^{13}$ and 1881-82.14 The Strafford county commissioners, in their report for $1883-84^{15}$, spoke of the need of more work. The Hills-

L Laws, 1800, ch. 7, sec. 1.

a p. 23.

$11 \mathrm{P} .26$.

4. P. 10. 
borough county commissioners in 1898 alluded to the large increase in commitments to their institution and said: "If this class of inmates continues to increase some indoor work should be provided to keep them from idleness and bring some income to the county especially in the winter months." 16 A somewhat similar sentiment was expressed two years later by the Grafton county commissioners. ${ }^{17}$

Unfortunately, however, the situation as to number of commitments grew worse instead of better. Hillsborough commitments increased from 229 in 1898 to 673 in 1905; Grafton from 49 in 1900 to 166 in 1905 . The increase in other counties was about equally grave. Besides the slight normal growth of misdemeanancy in this period, the counties had to reckon with the results of the adoption of local option license in place of prohibition in 1903..$^{18}$ So enormous was the increase of drunkenness, and 90 to 95 per cent of the minor offenders are committed for drunks, that new means had to be formed to enforce the law against this offense. Before this the enforcement of the law had been solely in the hands of the local police, and the town treasury had been responsible in most cases for the support of drunks at the houses of correction. To counteract the temptation to lax law enforcement, the legislature had, in view of the increase in drunkenness, to take a hand. Consequently, in 1905, a law ${ }^{19}$ was passed directing the state or county officers to prosecute at the expense of the town or city where local officers did not. Further the expenses of detention of drunks in county jails or at county houses of correction were transferred from the town or city to the county. Consequently more drunks were gathered in by the police, and the municipal courts were far more liberal in sentencing to imprisonment, the expense of the same being upon the county rather than the town. Consequently, also, the last remaining local houses of correction soon went out of business. It as surely followed that the labor market at the county farms was more than ever glutted.

Several counties have, from time to time, made experiments in indoor industries, but every experiment has been a failure. The truth of the matter seems to be that the admirable out-door activities furnished at the county farm are too restricted to keep all the prisoners reasonably employed, and that the prisoners are too few to make

16 Hillsborough Commissioners' Report, 1808 , p. 256.

17 Grafton Commissioners' Report, 1000, p. 138.

11 Laws, ro03. ch. 95.

10 Laws, roos, ch. 105. 
indoor industries reasonably profitable. When a rainy fall day, or the average winter day, restricts the men to only ten per cent of their labor efficiency we have, practically speaking, enforced idleness. It cannot be said that the humanitarian hopes of those who favored the application of prison labor to the county farms have been measureably realized.

It is therefore at once apparent, if the men are not worked to their full-time efficiency, that the second hope as to a substantial saving in the support of paupers is equally far from realization. Any short-term drunk, employed at full time, is not worth more than a quarter to a half as much as an average hired farm-hand. This is notorious among those who have had to do with the problem. If such a prisoner has not enough work to keep him busy, he is worth even less. In 1884, before the conditions were so acute as now, the Strafford commissioners were anxious for more work for the prisoners as a source of reventue to the county. More recently, in 1907, the Cheshire commissioners, after briefly reviewing the situation, came to the conclusion that the maintenance of the prisoners was quite an expense in the aggregate. ${ }^{2 n}$ Exact statistics are impossible, but the writer, after a rather careful inquiry, has reached the same conclusion as the Cheshire commissioners. Most of the other commissioners are of the opposite view, but the Cheshire commissioners and the writer have unbiased support from the State Board of Charities and Correction. ${ }^{21}$

There are two possible methods of dealing with the situation. First, keep on sending drunks to the county farms, but lengthen their terms and make them more efficient, exercising some superior ingenuity in trying to discover indoor industries to keep them reasonably busy. Second, recognizing the practical failure of the experiment so far from both economical and humanitarian standpoints, give up further experimentation at the county farms, remove all prisoners to a central state farm, and there work out the problem with a larger group better adapted to industrial organization, under leadership more expert than can be obtained with the present groups, and with the economies and efficiencies supposed to follow combination. The latter is the solution urged by the State Board of Charities and Correction in order that the prisoners may be thoroughly separated from

"Cheshire Commissioners' Report, 1007, p. 83.

neport, 1903-4, p. 66. 
the paupers. At the present time it is under consideration by a special commission authorized by act of the last legislature. The problem presented is by no means a simple one and historical considerations are such as to make the change hard rather than easy. It is interesting to note that if New Hampshire should abandon the experiment which gives this article its title and have a state workhouse for minor offenders separated from paupers, it would have such an institution as was contemplated for the province before the Revolution. ${ }^{22}$ Were our great-great-grandfathers wiser than we?

2 Provincial Laws, I771, p. 73. 